\title{
（3）疫学的，X線学的にみた上気道と下気道の相関
}

\author{
白幡 雄一（東歯大市川総合病院）
}

1.はじめに副䔬腔気管支症候群の成因にまつわる 上気道と下気道の相関を，慢性副鼻腔炎と気、管支拉張 症が併発するいわゆる副鼻腔気管支抬張症を通して検 討した。

2. 対象ならU゙に方法 対象は照路加国際病院内科, 耳曽科を受診し，症候学的，X線学的に診断され，入 院治療をうけた気管支拡張症の98例と，手術を受け組 織学的に診断された慢性副竟腔炎60例である。これら の患者の病歴, 胸部X線・副鼻腔X線写真をレトロス ペテクテブに検討した。

\section{3. 成績ならびに考察}

a. 合併頻度；慢性副其腔炎60例中 3 例 (5\%) に症 候学的，X線学的に気管支拡張症が認められた。一方, 98例の気管支拡張症中，44例 (45\%) に慢性副鼻腔炎 が認められた。副鼻腔病変と胸部病恋の灰表側の割合 を検討した，副鼻腔気管支搪張症では两側の副舅腔病 変と胸部病変を有する率が特発性気管支拡張症や慢性 副鼻腔炎に比べ有意に高く認められた。これを病態生 理学的な立場から言うと片側性病巣を有するものは局 部的原因があることが多く，両側性，対称的に発生す る病変は病因として素因が重視される。

b. 入院時年齡分布：発病の部位や症候も異なる慢性 副鼻空炎と気管支抬張症を同列には論じえないが，

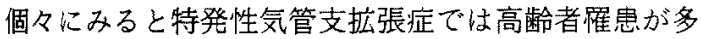
く，慢性副鼻腔炎では若年者䍜患が多い上いう傾向が 同えた。.上気道病変は喕接観察されるのに比べ，下気 道病変は形態的変化在捉えにくいため, 副奥腔気管支 拡張症では舅副鼻腔炎症状の先行が必ずしも病変の先 行を意味しない.小数例ではあるが10歳以下の幼少照 にみられた慢性副鼻空炎と気管支搪張症の合併 (2/44

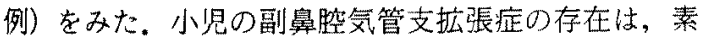
因を背景に形成された上・下気道の感染病変であるこ とを考えさせる。

c . 既往歴; 副鼻腔気管支抎張症と慢性副鼻腔炎, 特 発性気管支拡張症の既往歴を比較した。副鼻腔気管支
拡張症では特発性気管支拡張症に比バ喘息や委アレル ギーの既往歴を有するものが多く，また，習慣性アン ギー十や中耳炎, 肺炎または気管支炎の既往歴を有す るものが多く認められた。上気道と下気道共通のアレ ルギ一病態は感染团子による修飾を受けやすく，また 小児期に方ける呼吸器疾患は後䁷漏等の刺激性物質に 対する感受性を高めたり，感染症に罹患しやすくする 原因となることが考えられた。

d. 自賞症状：副鼻腔気管支拡張症で仗気管支炎症状 である発熱, 湿性の咳や拡張症の存在を暗示する脤血 痰が高率に認められた。また，器症状では慢性副睤腔 炎の主症状である鼻漏, 後鼻漏, 鼻閉が認められた。 診断時期を異にする副賞腔気管支拡張症の副鼻腔炎と 对象とした手術時の副鼻腔炎を同列に比較はできない

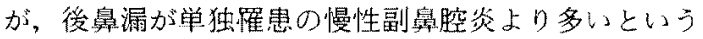
結果は得られなかった。

e 、䁷副鼾腔単純 X線所見：総じて慢性副鼻腔炎は副 鼻腔気管支拡張症の副鼻腔炎X線像上り高度病変を示 した。また，X線学的には副舅腔炎病像が認めら饥な い病例も副鼻腔気管支应張症では 3 例 (11\%) 存在し

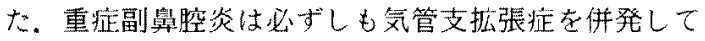
いない.

f. 副鼻腔炎の胸部 X線; 慢性副鼻腔炎患者70例の胸 部X写真検討し，副鼻腔炎や胸部疾患の睡往歴寺毛 たない患者70例の胸部X線写真と比較した。慢性副奥 腔炎患者の胸部X線像に岄筋ばった影やつぶつぶの影 が多く認めら机る傾向を示した，慢性副率腔炎患者の 胸部X線像に肺の間質性病変を示唆する陰影が多く認 められる傾向を示したことから，慢性副鼻腔炎患者の 下気道にも早い時期に潜在性の炎症が起きてきている ことが示惨された。

4.おわりに SBSの成因にはとりわけ気道の脆弱 (自己防衛機構低下) をもたらす素因が重要であること を述ベた。

\section{（4）副鼻腔気管支症候群の成因について}

\author{
洲 畸 春 海（東大）
}

副鼻腔気管支症候群 (sinobronchial syndrome, 以 下SBS と略す) は, 慢性副鼻腔炎と非特異的慢性気管 支炎症性疾患（慢性気管支炎，気管支拡張症，びまん 性沉細気管支炎) とを合併するものをいう. SBS 小小 児例では成人例と病態的に差異があり，多くの症例が 湿性咳嗽を長期的間持続する遷延性気管支炎や反復性 気管支炎といわれる状態である。小児のSBSは，小児
副鼻腔炎や気管支病変の特殊性から成人のSBS とは 別にして検討する心要がある。本稿では，成人のSBS を対象として，その成因について述べる。また，SBS に関連する特殊な例としてPrimary ciliary dyskinesia (Kartagener 症候群, immotile cilia 症候 群を含む)，膵臟裂胞線維症などがあるが、今回は対象 から除外した。 